\title{
Effect of Various Parameters on Augmentation of Distillate Output of Solar Still: A Review
}

\author{
Hitesh N. Panchal ${ }^{1} \cdot$ Sanjay Patel ${ }^{2}$
}

Received: 1 January 2016 / Accepted: 31 January 2016 / Published online: 24 February 2016

(C) Springer Science+Business Media Singapore 2016

\begin{abstract}
A Simple device which is used to obtain fresh water from saline water with the use of solar desalination process is known as solar still. The simple solar still give an output of 2.5 to 5 litres per $1 \mathrm{~m}^{2}$ area per day during bright sunshine hours. Hence various investigation has been done by scientists and researcher to improve the performance of solar still by inspecting various design parameters(water depth, condensing cover material, its thickness and inclination, type of solar still), climatic parameters(wind velocity, ambient temperature, solar radiation), operational parameters (salinity of water) which affect the production rate of solar still. In this review paper an attempt has been made to evaluate the effect of different design, climatic \& operational parameters that affect the performance of solar still.
\end{abstract}

Keywords Solar still · Design parameter · Climatic parameter · Operational parameter

\section{Introduction}

Water is the basic requirement for human being to live on earth. The water available on earth is in higher proportion compared to surface. Most of the amount of water is saline

Hitesh N. Panchal

engineerhitesh2000@gmail.com

1 Mechanical Engineering Department, Gujarat Power Engineering \& Research Institute, Mehsana, India

2 PG (Thermal Engineering) Research Scholar, Department of Mechanical Engineering, Sal Institute of Technology \& Engineering Research, Ahmedabad, India water which is available in ocean. Small amount of fresh water which is available in the form of rivers, lakes etc. Also there is a rapid growth of industries, population, agriculture production and many more such community demands of the pure water increasing.morever most of the diseases to the man are arise due to drinking impure water. Due to decreasing the available fresh water and rapidly increasing the demand of fresh water it is required to obtained fresh water from impure water. For this solar desalination is one of the important option to obtain pure water from impure water with the help of abundant available solar radiation heat energy and the instrument which is required to do this process is known as solar still.

Glass cover is very necessary component in the solar still. Panchal and Shah [1] found that, lower glass cover thickness, enhanced the performance of solar still. Panchal and Shah [2] also carried out the comparison of CFD results and experimental results on solar still glass cover thickness and found good agreement. Kaushal and Varun [3] prepared an analysis for the different types of solar still. The objective of this review paper is to present the investigation of different design, climatic \& operational parameter that affects the performance of solar still.

\section{Working Principal of Simple Solar Still}

The working of the actual solar still is similar to the nature's hydrological cycle. In natural distillation solar radiation is incident on the ocean water and causes water to evaporate and the evaporated water rises above the earth's surfaces due to low density and moved by current of air. When this steam is cools down to its dew point temperature condensation procedure start and pure water comes down as rain. The primary process is responsible for the nature's hydrological 
cycle. This similar hypothesis evaporation and condensation is utilized for the separation of saline water and clean water in any solar distillation system.

The simple sketch of solar still showing its working is shown in Fig. 1. It consists of a shallow blackened basin fill with saline water and whole structured enclosed by a sloping transparent cover. Solar radiation transmit through the transparent cover and incident on the basin water causes it to evaporate then evaporated vapours condensed on the inner side of the glass cover and fall down due to gravity gathered in a distillate channel. According to the research done solar still are classified into two categories name it as active distiller and passive distiller. In active solar still supplementary collector, mechanical or electrical energy is used to improve the output. In passive solar still straightforward modification is done inside the basin to improve its output.

\section{Factors Affecting the Performance of Solar Still}

The distillate output of solar still depends on the climatic parameters such as solar radiation intensity, wind velocity, ambient temperature etc. Also the design parameters such as brine depth, insulation, cover material \& its thickness, inclination of glass cover and operational parameters such as preheating of feed water, salinity of water that affect the yield of solar still. Hence the main aim of this review paper is to shows the investigation done on the different design, climatic and operational parameters that affect the yield of solar still.

\section{Investigation of the Design Parameters of Solar Still}

\section{Water Depth}

One of the most important design parameters that affect the yield of solar still is water depth. Water depth affects the

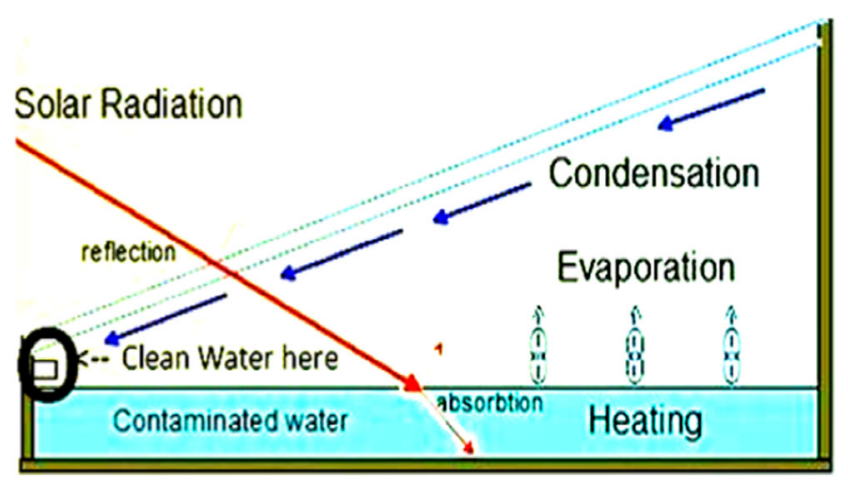

Fig. 1 Simple sketch of solar still showing its working

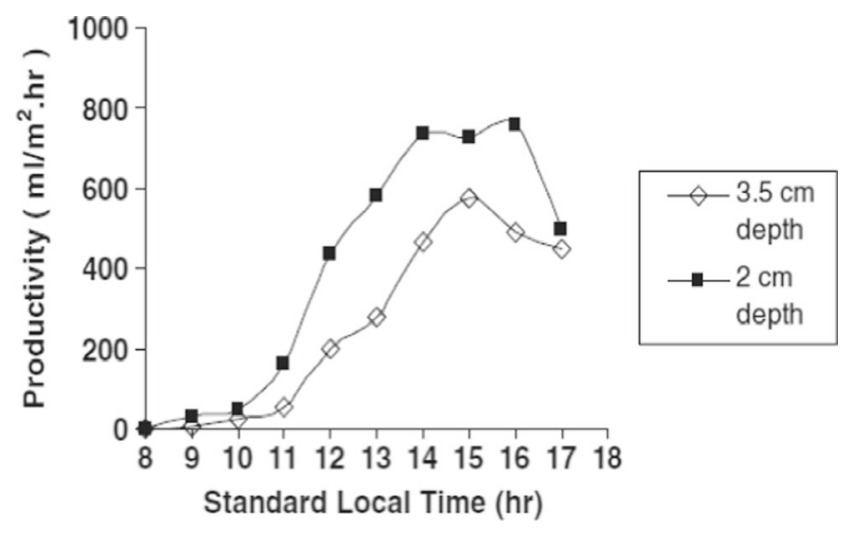

Fig. 2 Hourly distillate output vs time [4]

rate of evaporation and ultimately the yield of still.So that many scientists investigated the effect of water depth on the yield of different configuration of solar still at different place and concluded that minimum water depth gives maximum output.

Badran and Abu-Khader [4] has carried out experimental and theoretical investigation to examine the effect of water depth of $2 \mathrm{~cm} \& 3.5 \mathrm{~cm}$ on a single slope single basin solar still. Test were done on $1^{\text {st }}$ April 2004 and result shows that output of $25.7 \%$ increase by decreasing water depth from $3.5 \mathrm{~cm}$ to $2 \mathrm{~cm}$. Figure 2 shows the hourly distillate output with time for different water depth.

Experimental Test were conducted by Kandasamy et al. [5] to inspect the performance of double slope solar still for six different water depth of 1 to $6 \mathrm{~cm}$.also performance correlation was developed and compared with experimental result. Figure 3 shows deviation in the yield of still for different brine depth. It was observed from the graph that maximum yield obtained at minimum brine depth due to rapid evaporation.

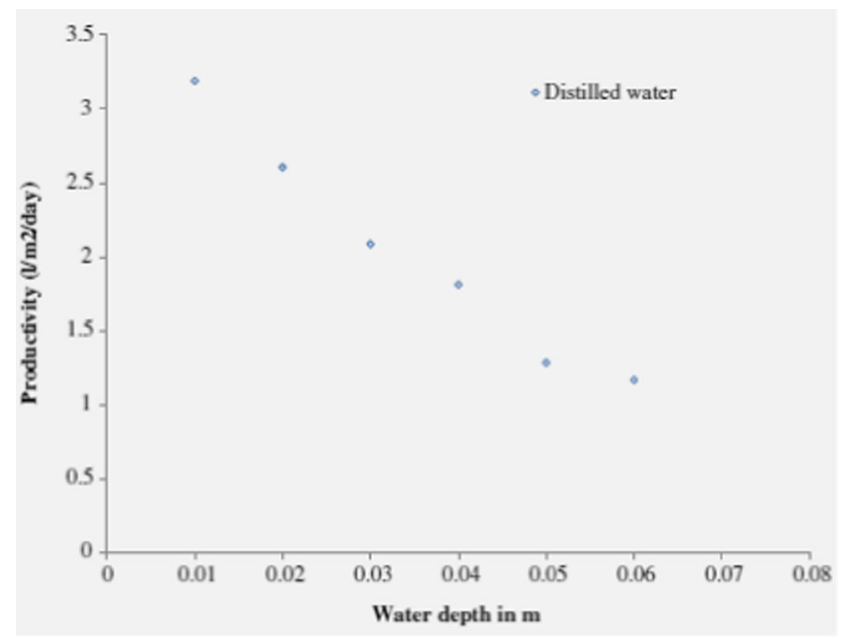

Fig. 3 Shows deviation in the yield of still for different brine depth [5] 


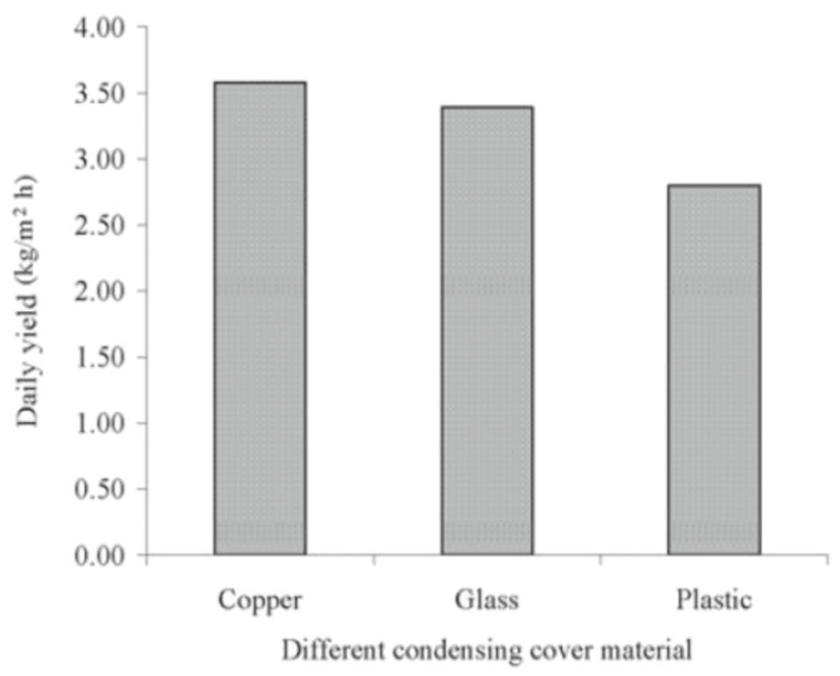

Fig. 4 Daily yield for different condensing cover material for a still connected with flat plate collector [6]

\section{Condensing Cover Material, Thickness \& its Inclination}

Tiwari et al. [6] investigated the impact of different condensing cover material like copper, glass \& plastic on the daily yield and conclude that copper gives higher yield due to higher thermal conductivity compared to glass \& plastic as shown in Fig. 4.

Tiwari et al. [6] also investigated the impact of different thickness of glass cover ranging from 2 to $6 \mathrm{~mm}$ for passive solar still \& solar still joined with flat plate collector and reports that with increasing glass cover thickness there is a reduction on the yield is noted for both active and passive mode as shown in Fig. 5.

Tiwari and Tiwari [7] have conduct an experiment for three different condensing cover inclination namely $15^{\circ}$, $30^{\circ} \& 45^{\circ}$ for a passive solar still through the year of clear sky daily over $24 \mathrm{hr}$ under climatic condition of New Delhi and conclude that $15^{\circ}$ is the best inclination angle for single slope passive solar still for the yield and efficiency for

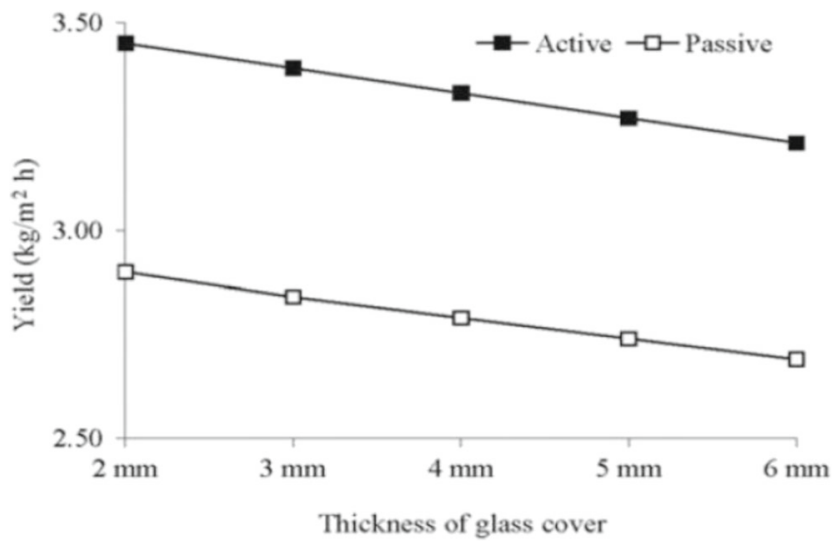

Fig. 5 Variation of yield on different thickness of glass covers [6] annual performance and said that minimum angle is preferred in summer and rainy seasons and maximum angle is preferred in winter.

\section{Types of Solar Still}

\section{Single Basin Solar Still-Passive}

An experimental work has been carried out by Badran [8] to predict the performance of single slope solar still with the enhancers like asphalt basin liner and sprinkler. Figure 6 Shows pie chart of contribution of daily and overnight productivity which conclude that night production is $16 \%$ than daily productivity. Also it can be conclude that when combined enhancers such as asphalt basin liner and sprinkler is used, the still productivity is increased by $51 \%$ and impart $16 \%$ of daily production to night production.

Abdallaha et al. [9] have design and fabricated four solar still units with same dimensions and studied the effect of different absorbing material like coated metallic wiry sponge, uncoated metallic wiry sponge and black rocks and compared with reference still having no absorbing material and conclude that black rocks absorbs, store and realese the incident solar energy better than remaining absorbing material and its productivity is nearly $20 \%$ more than coated metallic \& uncoated metallic wiry sponge. Also shows that overnight productivity of black rocks is $60 \%$ followed by $43 \%$ of uncoated wiry sponges and $28 \%$ of coated wiry sponges. Figure 7 Shows overnight productivity variation for three different days of experiment with and without absorbing materials.

Experimental study has been performed for a single slope single basin solar still with different floating absorber plate by El-Bialy [10] and compared with conventional solar still in the identical weather situation of Tanta, Egypt during summer days. He had used mica, aluminum; copper and stainless steel as floating absorber plate and concludes that the improvement ratio of overnight productivity increase and daily and daylight productivity decrease with increasing

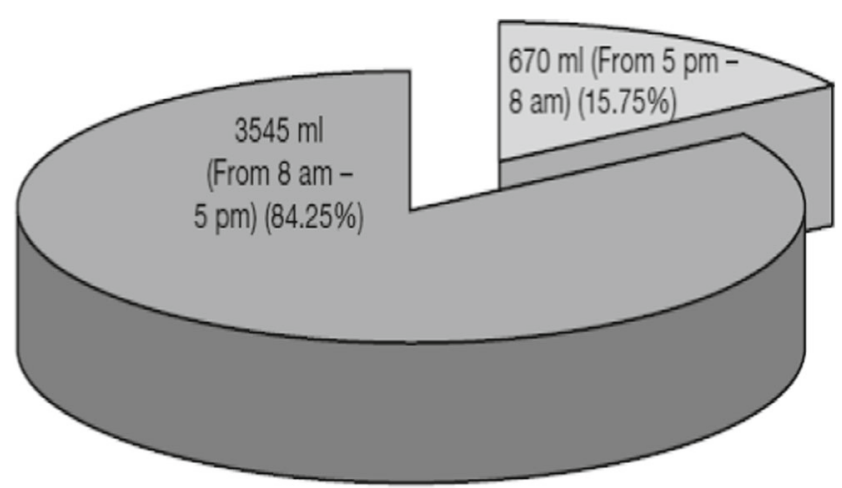

Fig. 6 Daylight and overnight output of still [8] 


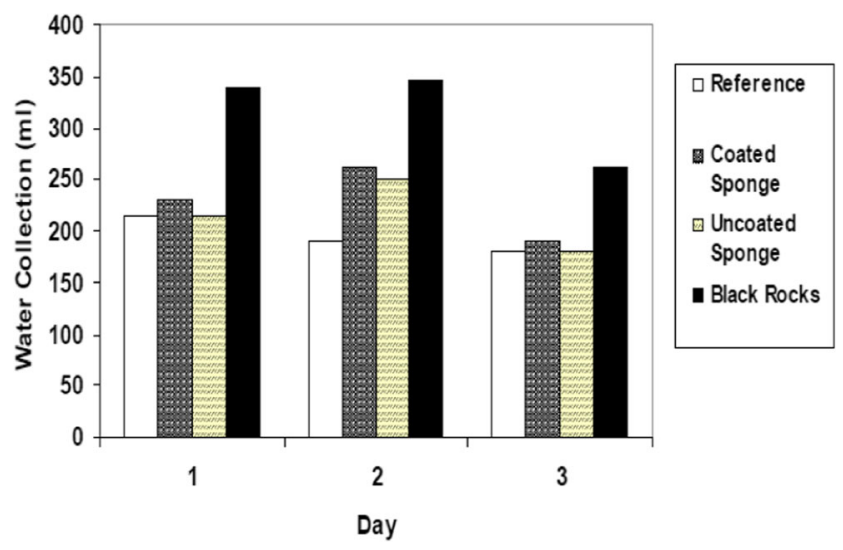

Fig. 7 Variation of overnight productivity for three days of experiment [9]

the mass of water above the absorber plate. Figure 8 shows the comparison of daylight, overnight and daily productivity between single basin solar still with and without floating absorber

\section{Single Basin Solar Still-Active}

Dwivedi and Tiwari [11] reports Experimental and theoretical study for a double slope active solar still under natural circulation mode on the basis of energy balance of east and west glass cover with collector facing to south with water depth of $0.03 \mathrm{~m}$. The result of experimental and theoretical data shows that double slope solar still joined with flat plate collector under natural circulation mode giving $51 \%$ higher output compared to conventional distiller. Figure 9 shows

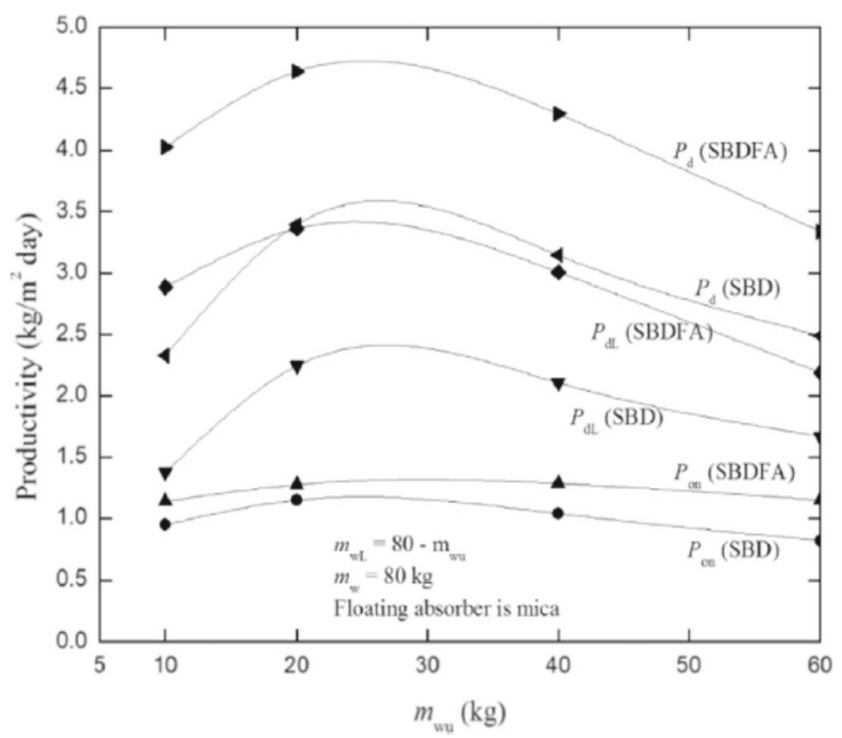

Fig. 8 Comparison of daylight, daily and overnight productivity of SBDFA with SBD [10]

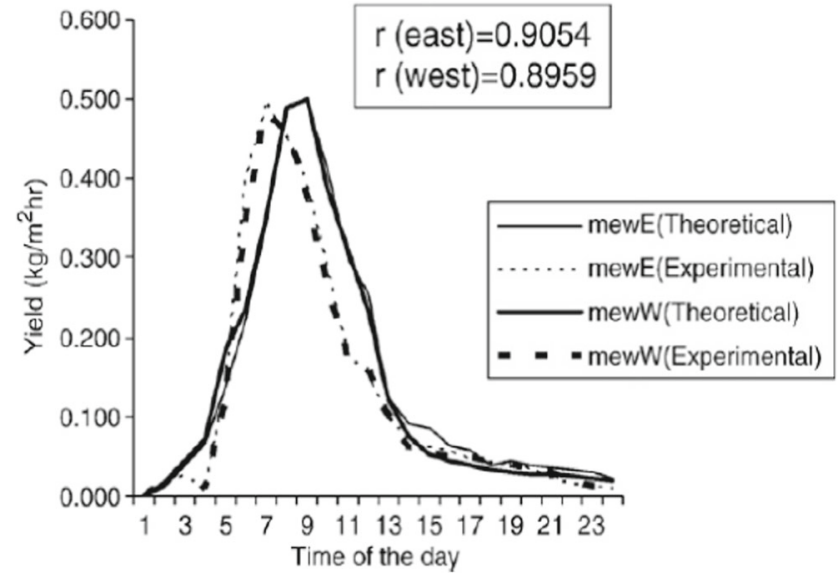

Fig. 9 Comparison of yield for experimental test and theoretical of double slope distiller connected with flat plate collector [11]

Comparison of yield for experimental test and theoretical of double slope distiller connected with flat plate collector.

The effect of coupling a flat-plate solar collector on the yield of solar still was carried out by Dimri and its co worker [6]. As shown in Fig. 10 it was observed from the experimental result that Yield of active solar still is noted more than passive solar still.

The efficiency of a simple basin solar still and similar one attached to a flat plate collector was investigated by Bouker and Harmin [12] under the effect of desert climatic condition of adrar, an Algeria Saharan site. Three month experiment shows that its yield is strongly depend on the solar radiation and ambient temperature. Panchal et al. [20] used heat pipes attached with solar still and found $30 \%$ increment in distillate output.

\section{Multi basin solar still- passive}

Due to small efficiency of single effect solar still some researchers modified a little bit on its construction with a

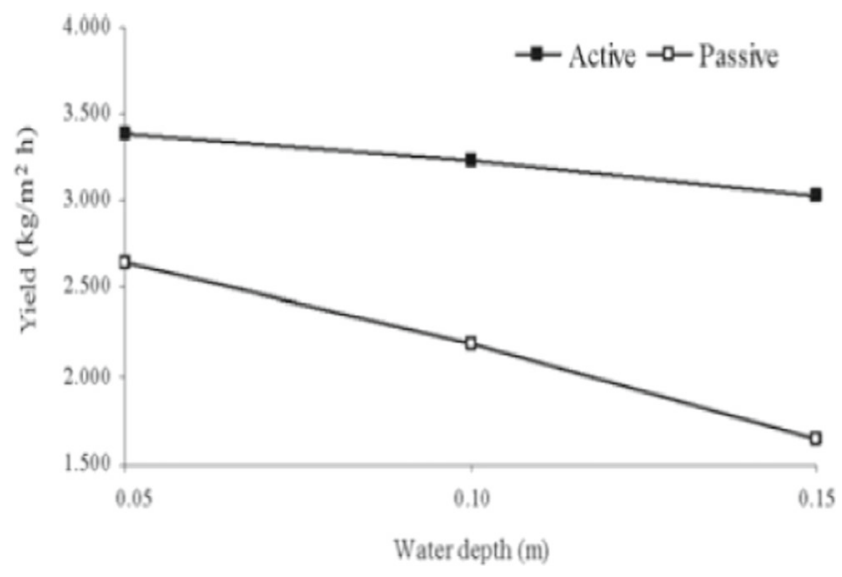

Fig. 10 Comparision of yield for active and passive solar still [6] 


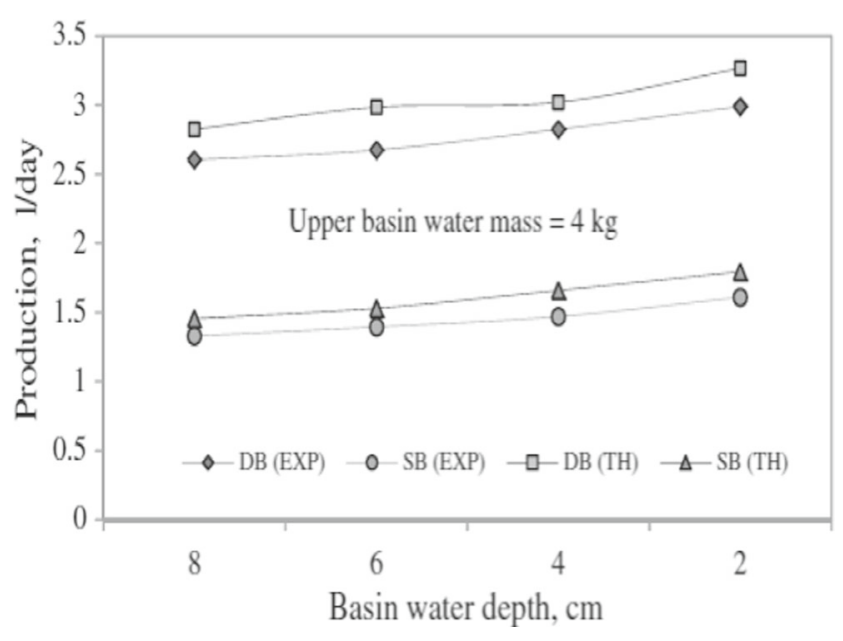

Fig. 11 Experimental and theoretical productivity for single and multi basin still vs different brine depth [13]

concept of multi basin because in single effect still latent heat of vaporizations release by the exterior side of glass cover is wasted to the surroundings whereas the multi basin have a advantage that the latent heat of vaporization of lower basin is used to heat the upper basin water through transparent glass cover.

A double basin double slope solar still was made-up by Rajaseenivasan and Kalidasa Murugavel [13] and experimentally \& theoretically study with different basin condition was also done. Study of different water depth in both upper and lower basin on yield of double basin still was carried out and the result of double basin still was compared with single basin still. Figure 11 indicates the comparison of productivity with different brine depth for single and multi basin with both theoretically and experimentally. It was observed that double basin still efficiency is higher than

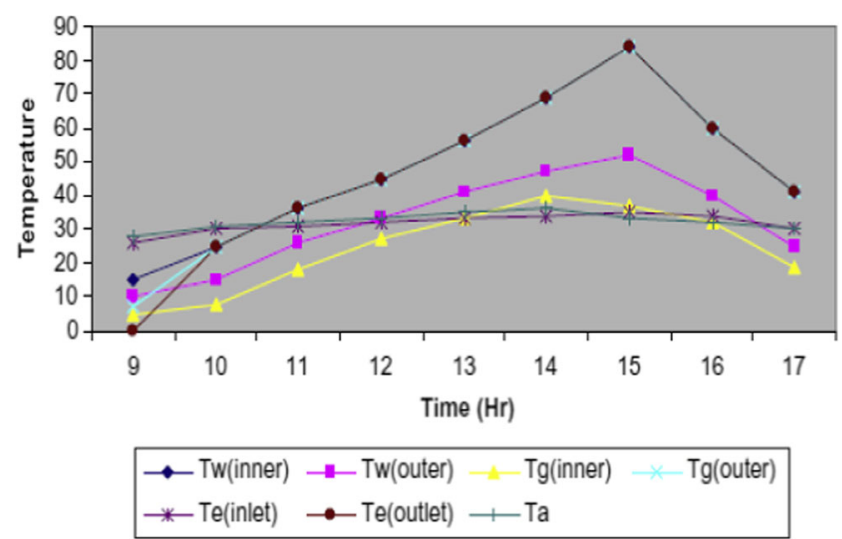

Fig. 13 Shows change in temperature with respect to time for double basin still [15]

the conventional solar still by $85 \%$ for the same basin condition. Highest water output of 2.99 litre/day $\left(4.75 \mathrm{l} / \mathrm{m}^{2}\right.$.day $)$ for double basin still was noted.

Performance study conducted by Elango [14] for different water depth from 1 to $5 \mathrm{~cm}$ under both insulated and uninsulated conditions.comparision of yield for single basin ad double basin solar still for insulated and uninsulated condition is shown in Fig. 12. The experimental result shows that at $1 \mathrm{~cm}$ water depth $17.38 \%$ output is noted for double basin insulated still and uninsulated still gives $8.12 \%$ output more than conventional still.

\section{Multi Basin Solar Still-Active}

The still efficiency mostly depends on the temperature difference between basin water and interior side condensing glass cover temperature. As the water temperature increase the temperature difference between evaporating and condensing surface increase. One of the major drawbacks of
Fig. 12 Comparisons of yield for single basin ad multi basin solar still for insulated and uninsulated condition [14]

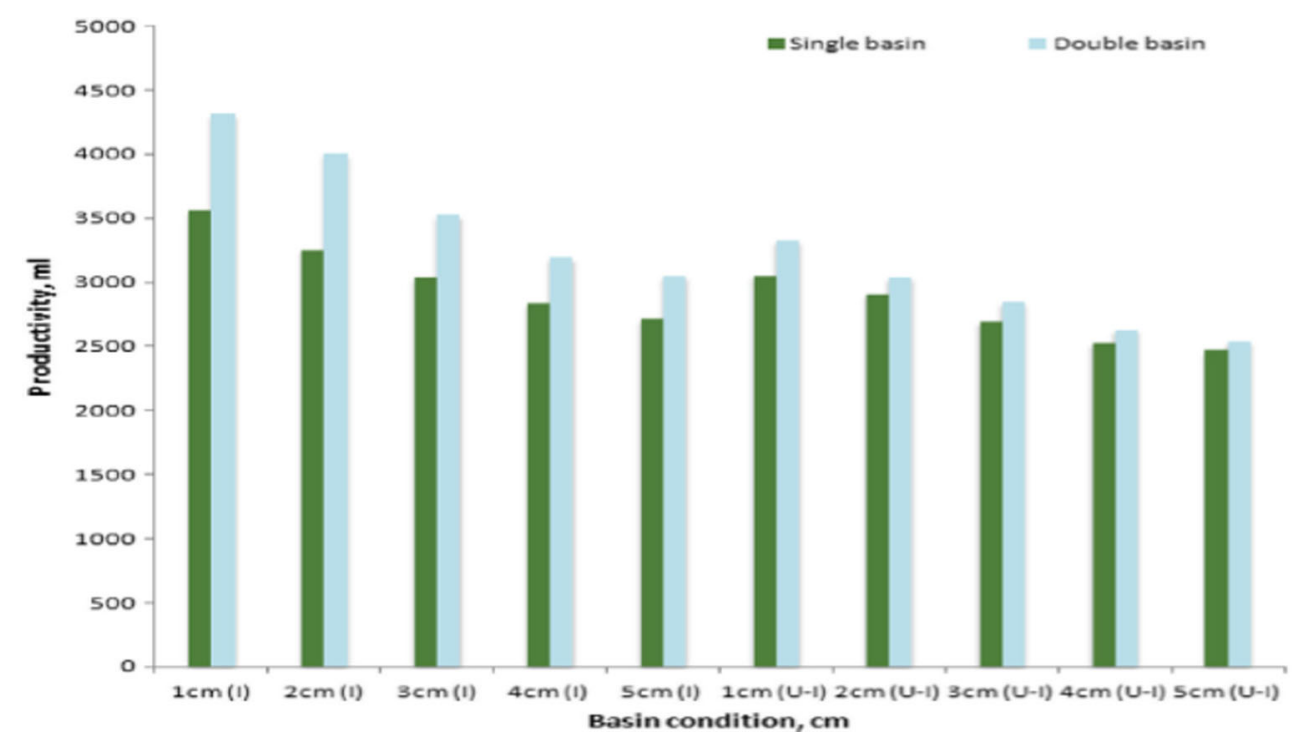


multi basin still is that lower basin collect lower radiation than upper basin because of Transmitivity introduced by adding multi basin. Hence it is necessary to increase the thermal energy from external sources.

Experimental analysis was reported by Panchal [15] to examine the effect of coupling evacuated tubes to the lower basin of double basin single slope solar still with and without using black granite gravel as energy absorbing material. the performance of double basin still alone and with still attached with evacuated tubes investigated with and without black granite gravel. Result shows that distillate output is increase by $56 \%$ with coupling evacuated tubes and $65 \%$ with evacuated tubes and black granite gravel. Also economic analysis carried out and shows that within 195days cost of still is recovered. Panchal and Shah [19] used double basin solar still with different mass of water and found $4 \mathrm{~cm}$ depth enhances the distillate output (Fig. 13).

\section{Investigation of the Climatic Parameters of Solar Still}

\section{Wind Velocity}

Variation of Wind speed affects the production of solar still. As the wind speed increase the convective heat transfer coefficient from glass cover to the surrounding increase and temperature difference between water and inner side glass cover increase and eventually performance of solar still increase [6].

Indoor test was carried out by Khalifa and Ali [16] to inspect the impact of wind speed on still performance and efficiency. The test was carried out at four different wind speeds of $1.14,2.06,2.92$ and $4.01 \mathrm{~m} / \mathrm{s}$ and compared with

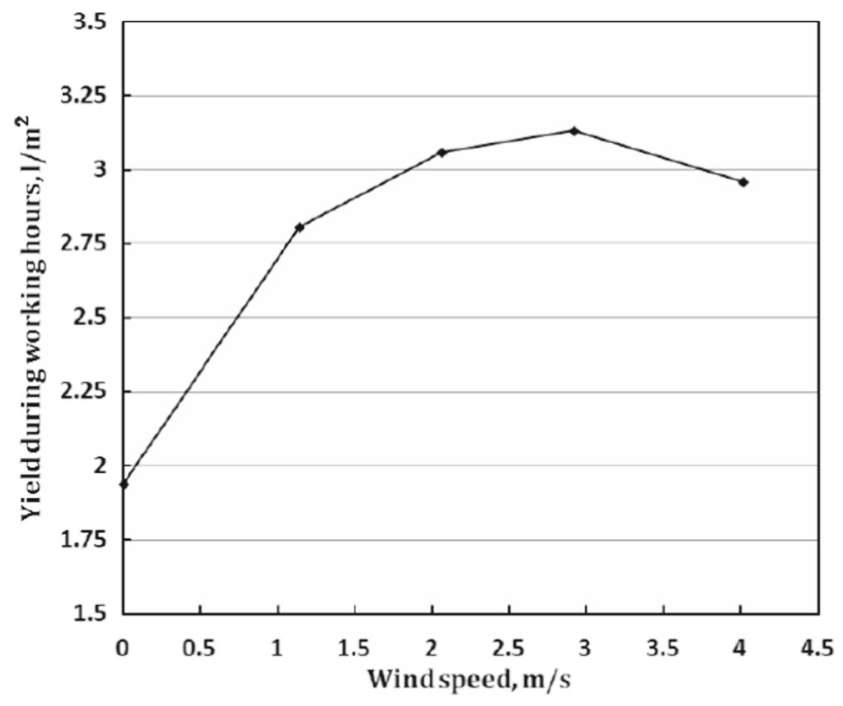

Fig. 14 Shows change in yield of solar still vs wind speed [16] no wind. It was found that performance of solar still increase with increasing wind speed and high wind speed give less development in yield than reasonable wind speed. Figure 14 shows change in yield of solar still vs wind speed. it was found that maximum yield obtained at $2.92 \mathrm{~m} / \mathrm{s}$ wind speed. So he concludes that moderate wind speed increase the output of solar still.

\section{Ambient Temperature}

Ambient Temperature also affects the still productivity. Increase in ambient temperature still productivity is increase [17].

\section{Solar Radiation}

Distillation require heat energy to evaporate the water and this heat energy is obtained by solar Radiation which is available abundant at any place, never lasting and pollution free. But it's intensity varies day by day, season to season Which affect the daily yield of solar still.

Badran and Abu-Khader [4] reported an effect of solar intensity on the yield of still with respect to time Fig. 15 variations in intensity of solar radiation vs time in hours. It was observed that maximum solar radiation intensity obtained in the period of 12 to $2 \mathrm{pm}$ which lead to increase in output of still.

Figure 16 shows that solar radiation intensity recorded on the suez city in month of May 1998. It was found that maximum yield was obtained during afternoon hours due to high intensity.

\section{Investigation of the Operational Parameters of Solar Still}

\section{Salinity of Water}

Akash et al. [17] has studied the effect of salinity of water on solar distillation and conclude that clean water production decrease with increasing salinity.

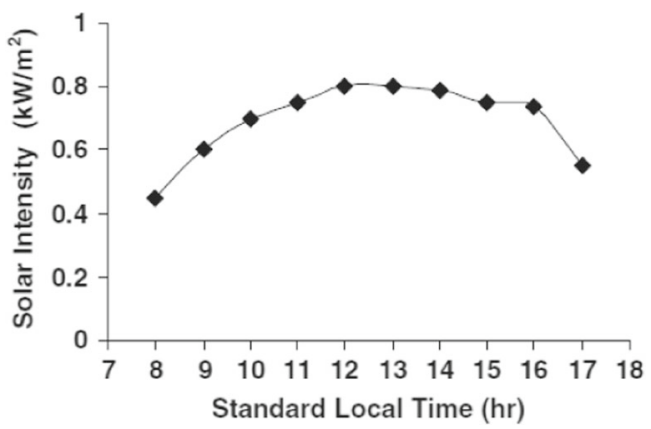

Fig. 15 Variations in intensity of solar radiation vs time in hours [4] 


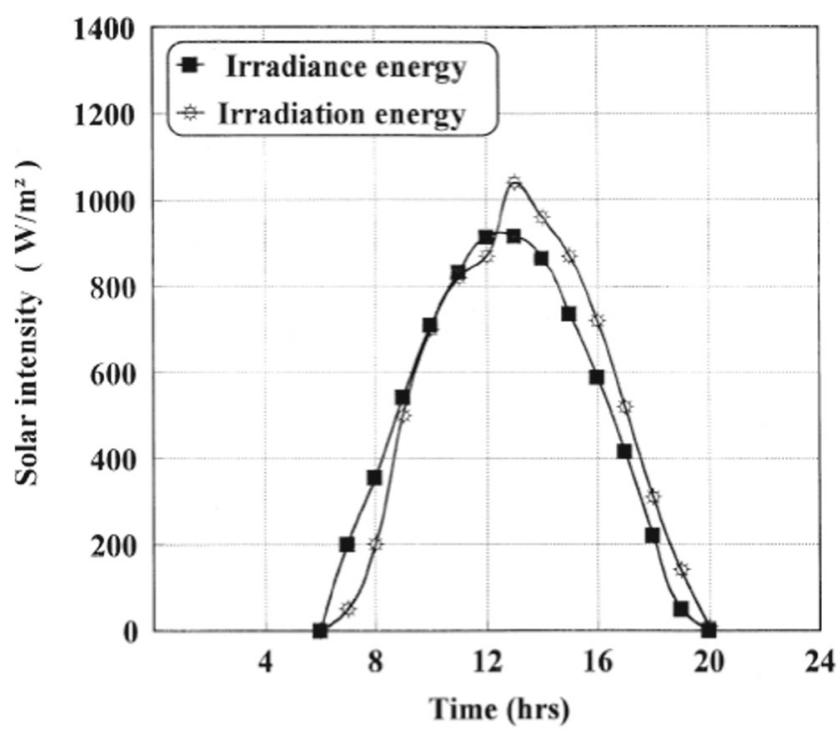

Fig. 16 Variation of solar radiation intensity with time in hours [18]

\section{Outcome}

Table 1 shows the summary of different design, climatic and operational parameter cited in this article. Also the following key point summarizes the above discussion:
- It is recommended to use minimum brine depth for increasing daily yield. Because at higher brine depth evaporation rate is decreasing.

- Performance of still is associated with thermal conductivity of cover material.

- Lower thickness of condensing glass cover is preferred.

- Inclination of glass cover is very important for increase in productivity. It is suggested that larger cover tilt angle should be preferred in winter and smaller angle is preferred in summer and it is also observed that finest cover tilt angle is near about the latitude angle of the place.

- Black granite gravel and black rocks are good energy absorbing material to store the solar energy and increase the productivity.

- Use of Asphalt Basin liner increase the productivity of solar still due to higher absorbency compared to black paint.

- Integrating the flat plate collector with distiller increase the output of still.

- Output of Multi-basin solar still is more than the single basin solar still.

- Double-basin solar still coupled with vacuum tubes gives higher yield.

Table 1 Summary of different design, climatic and operational parameters cited in this review paper

\begin{tabular}{|c|c|c|c|}
\hline Sr.No & Researcher & Investigated parameter & Performance of distiller \\
\hline 1 & Abu-Khader et al. [4] & Water depth & Still productivity of $25.7 \%$ increase by deceasing water depth from $3.5 \mathrm{~cm}$ to $2 \mathrm{~cm}$. \\
\hline 2 & Kandasamy et al. [5] & Water depth & Maximum still productivity is obtained at mimimum brine depth. \\
\hline 3 & Tiwari et al. [6] & Condensing cover material & $\begin{array}{l}\text { High thermal conductivity material gives higher output like copper in this research } \\
\text { case compared to glass and plastic. }\end{array}$ \\
\hline 4 & Tiwari et al. [6] & Thickness of cover & Yield is maximum at low thickness of cover. \\
\hline 5 & Tiwari and Tiwari [7] & Tilt angle of glass cover & $\begin{array}{l}15^{\circ} \text { inclination angle gives greater annual yield \& efficiency for single basin } \\
\text { single slope solar still in summer and monsoon \& } 45^{\circ} \text { is the best for winter } \\
\text { season at place of New Delhi. }\end{array}$ \\
\hline 6 & Badran [8] & Single basin still-passive & $\begin{array}{l}29 \% \text { \& } 51 \% \text { yield is increase by use of asphalt \& combination of asphalt } \\
\text { and sprinkler. }\end{array}$ \\
\hline 7 & Abu-Khader et al. [9] & Single basin still-passive & $\begin{array}{l}\text { Use of coated, uncoated metallic wiry sponge \& black rocks increase the } \\
\text { productivity by } 28 \%, 43 \% \& 60 \% \text { respectively. }\end{array}$ \\
\hline 8 & Dwivedi and Tiwari [11] & Single basin still-active & $\begin{array}{l}\text { Passive solar still gives daily yield of } 1.838 \mathrm{~kg} / \mathrm{m}^{2} \text { and active solar still } \\
\text { gives daily yield of } 2.791 \mathrm{~kg} / \mathrm{m}^{2} \text {. }\end{array}$ \\
\hline 9 & Elango et al. [14] & Multi basin still-passive & $\begin{array}{l}\text { At } 1 \mathrm{~cm} \text { brine depth still yield is noted as } 5.31 / \mathrm{m}^{2} / \text { day for insulated multi } \\
\text { basin still \& } 4.4 \mathrm{l} / \mathrm{m}^{2} / \text { day for insulated single basin passive still }\end{array}$ \\
\hline 10 & Panchal [15] & Multi basin still-active & $\begin{array}{l}\text { Combination of evacuated tubes \& black granite gravel increase the } \\
\text { output by } 56 \% \text {. }\end{array}$ \\
\hline 11 & Khalifa et al. [16] & Wind speed & $\begin{array}{l}\text { Still yield at } 1.14 \mathrm{~m} / \mathrm{s}, 2.06 \mathrm{~m} / \mathrm{s}, 2.92 \mathrm{~m} / \mathrm{s} \& 4.01 \mathrm{~m} / \mathrm{s} \text { wind speed is } 44.7 \% \text {, } \\
53.8 \%, 56.3 \% \text { \& } 50.2 \% \text { respectively. }\end{array}$ \\
\hline 12 & Badran et al. [4] & Solar radiation & $\begin{array}{l}\text { In afternoon greater yield is obtained because of high intensity of } \\
\text { solar radiation }\end{array}$ \\
\hline 13 & Akash et al. [17] & Salinity of water & At poor concentration saline water affects the efficiency of still. \\
\hline
\end{tabular}


- Productivity of still increase with increasing wind speed but performance of still little bit decrease with higher wind speed.

- The salinity of water affects yield even at low concentration it decrease with increasing salinity.

\section{References}

1. Panchal H, Shah P (2012) Effect of varying glass cover thickness on performance of solar still: in a winter climate conditions. Int $\mathrm{J}$ Renew Energy Res 1(4):212-223

2. Panchal H, Shah P (2011) Modelling and verification of single slope solar still using ANSYS-CFX. Int J Energy Environ 2(6):985-998

3. Kaushal A, Varun (2010) Solar stills: a review. Renew Sustain Energy Rev 14:446-453

4. Badran OO, Abu-Khader MM (2007) Evaluating thermal performance of a single slope solar still. Heat Mass Transf 43:985-995

5. Kandasamy S, Vellingiri M, Sengottain S, Balasundaram J (2013) Performance correlation for single-basin double-slope solar still. Int J Energy Environ 4:1-6

6. Dimri V, Sarkar B, Singh U, Tiwari GN (2008) Effect of condensing cover material on yield of an active solar still: an experimental validation. Elsevier. Desalination 227:178-189

7. Tiwari AK, Tiwari GN (2007) Annual performance analysis and thermal modeling of passive solar still for different inclinations of condensing cover. Int J Energy Res 31:1358-1382

8. Badran OO (2007) Experimental study of the enhancement parameters on a single slope solar still productivity. Desalination 209:136-143

9. Abdallaha S, Abu-Khaderb MM, Badranc O (2009) Effect of various absorbing materials on the thermal performance of solar stills. Elsevier. Desalination 242:128-137
10. El-Bialy E (2014) Performance analysis for passive single slope single basin solar distiller with a floating absorber: an experimental study. Elsevier. Energy 68:117-124

11. Dwivedi VK, Tiwari GN (2010) Experimental validation of thermal model of a double slope active solar still under natural circulation mode. Desalination 250:49-55

12. Boukar M, Harmin A (2001) Effect of climatic conditions on the performance of a simple basin solar still: a comparative study. Desalination 137:15-22

13. Rajaseenivasan T, Kalidasa Murugavel K (2013) Theoretical and experimental investigation on double basin double slope solar still. Desalination 319:25-32

14. Elango T, Kalidasa murugavel K (2015) The effect of the water depth on the productivity for single and double basin double slope glass solar stills. Elsevier. Desalination 359:82-91

15. Panchal HN (2015) Enhancement of distillate output of double basin solar still with vacuum tubes. J King Saud University - Eng Sci 27:170-175

16. Khalifa AJN, Ali MA (2015) Indoor tests on the effect of wind speed on still performance. Int J Energy Environ 6(3):299_ 308

17. Akash BA, Mohsen MS, Nayfeh W (2000) Experimental study of the basin type solar still under local climate conditions. Energy Convers Manag 41:883-890

18. Safwat Nafey A, Abdelkader M, Abdelmotalip A, Mabrouk AA (2000) Parameters affecting solar still productivity. Energy Convers Manag 41:1797-1809

19. Panchal HN, Shah PK Investigation on performance analysis of a novel design of the vacuum tube-assisted double basin solar still: an experimental approach. Int J Ambient Energy. doi:10.1080/01430750.2014.924435

20. Panchal HN, Doshi M, Patel A, Thakor K (2011) Experimental investigation on coupling evacuated heat pipe collector on single basin single slope solar still productivity. Int J Mech Eng Technol 2(1):1-9 